\title{
Socialist vs. Bourgeois Rights-An East-West German Comparison
}

\author{
Inga Markovits †
}

Individual rights are the connecting link between a citizen and the legal system under which he lives: they exemplify both what the citizen can expect from the law and what the law expects from him. In this article, I will examine the structure of rights under socialist and bourgeois ${ }^{1}$ law in order to compare the function of individual rights under both systems and in this way gain insight into the different meanings of "law" in socialist and bourgeois society.

I am interested in the ideology or theory of rights: not the theory proclaimed by politicians and scholars under both legal systems, nor (a likely topic in this context) the question of how well that theory, on the socialist side, squares with the teachings of the Marxist classics about law, ${ }^{2}$ but in that theoretical understanding of rights that can be extracted from the numerous ways in which individual rights are actually interpreted and handled in the legal process. How are rights viewed by those who deal with them; what is their purpose and justification? I think the answer to this question matters, because a legal system's ideology (or, if one wants, mythology) of rights will produce very tangible consequences in the ways in which rights are actually granted and protected. My comparison, though grounded on factual examples, will thus be fairly abstract: I will try to distill, from practical differences, the theoretical essence of bourgeois and socialist rights. As I will show towards the end of this article, these theoretical distinctions may well have practical value for the assessment of present developments and conflicts within socialist legal systems.

My comparison of the socialist and bourgeois understandings of rights will be based on the legal systems of East and West Germany. Both Germanies are civil law countries. They share the same histori-

$\dagger$ Dr. Jr. 1966, Freie Universität Berlin, LL.M. 1969, Yale University. Assistant Professor of Law, The University of Texas. The author wishes to thank the American Council of Learned Societies for a grant supporting the research that led to this study.

1 Throughout this article I will, for want of a better word, use the terms "bourgeois" and "capitalist" interchangeably to refer to the legal systems of West Germany and similar developed democratic Western states. I will also use the word "socialist" in a non-technical way to refer to the legal systems of the Soviet type.

2 Socialist understanding and use of law today has departed so far from its classic Marxist origins that references to Marxist concepts and terminology (though indispensable to socialist authors) are generally more confusing than enlightening. 
cal and legal past, have similar levels of industrial development, and similar types of populations. A comparison between the East and West German handling of rights will thus be as free as possible from the problems that beset a comparison of, for instance, American and Soviet law, where too many other things are not equal. Both German systems, furthermore, are typical of their respective bourgeois and socialist approaches to law. West German law, while preserving its traditional features, has been developed and modernized to fit the needs of a highly industrialized capitalist society. East German law has copied and adapted the Soviet example to a point where the breach with the bourgeois past seems complete. ${ }^{3}$ Nevertheless, some caveats are necessary. It must be remembered that, given the rise of Chinese, Cuban, and African versions of socialism, we can no longer speak of one socialist approach to law, and that therefore my comparison will be valid primarily for socialist legal systems following the Soviet model. Moreover, the civil law character of both German systems, while facilitating comparison, may raise questions about the applicability of my findings to common law countries. ${ }^{4}$ Within these limitations, however, the German situation should provide a laboratory setting for exploring the differences between the socialist and the bourgeois understanding of law.

This study is preliminary to a more comprehensive investigation into the different meanings of rights under bourgeois and socialist law now under preparation. In the present article, I want to anti-

${ }^{3}$ The final split between the two German legal systems occurred only in 1975 with East Germany's enactment of a new civil code. Zivilgesetzbuch (civil code) of June 19, 1975, [1975] Gesetzblatt der DDR [GBIDDR] I 465 (E. Ger.). The new code abolished in the German Democratic Republic (GDR) the last piece of common legislation, the old Birgerliches Gesetzbuch of 1900 , already largely replaced by amendments and special legislation to fit East German conditions. After an initial phase in which it substituted new socialist legislation for inherited bourgeois legislation, the GDR is now beginning to overhaul and update its new legal system .with a number of "second generation" socialist codes. See, e.g., Gesetz zur Ergänzung und Anderung der Verfassung der DDR (constitutional revision law) of Oct. 7, 1974, [1974] GBl.DDR I 425 (E. Ger.); Gerichtsverfassungsgesetz (court organization law) of Sept. 27, 1974, [1974] GBI.DDR I 457 (E. Ger.); Strafgesetzbuch (criminal code) of Dec. 19, 1974, [1975] GBl.DDR I 13 (E. Ger.); Arbeitsgesetzbuch (labor code) [AGB] of June 16, 1977, [1977] GBl.DDR I 185 (E. Ger.).

- An investigation into the distinctions between civil and common law systems lies beyond the scope of this article. However, civil and common law systems differ primarily in their style of reasoning and in their law of procedure, and I do not think that these differences will significantly affect the validity of my comparison. If anything, the common law understanding of rights appears to be more "bourgeois" in some respects than the West European civil law approach. If socialism seems unthinkable in a common law setting, it is not only because the common law's focus on private conflict would be at odds with a socialist understanding of rights, see text and notes at notes 5-26 infra, but also because its respect for precedents would discredit and hopelessly diffuse the central authority of a Party state. 
cipate and explore some of my expected results. For this purpose, I will first state what I take to be the most salient distinctions between bourgeois and socialist rights. On the basis of these distinctions I will outline the different underlying views of law. I will then investigate some inherent contradictions within the socialist approach to law. Finally, I will speculate about recently emerging "bourgeois" features in the socialist understanding of rights.

\section{Different Meanings of Rights under Socialist and Bourgeois LAW}

\section{A. The Political Purpose of Rights}

Bourgeois rights are entitlements; socialist rights are policy pronouncements.

As individual entitlements, bourgeois rights confer autonomy in a limited area, which then can be exercised at the discretion of the rightholder. In a way, all bourgeois rights are modelled after property rights: they map out territory, set up fences against prospective intruders, or, to quote Marx, they delineate the elbow room of the individual capitalist. Bourgeois rights are meant to be weapons; their cutting edge is their enforceability. ${ }^{5}$ West German constitutional rights may serve as an example. They are defensive rights, Abwehrrechte, ${ }^{6}$ which prevent the state from interfering with an enclave of personal autonomy. For instance, the Grundgesetz, in its promise of freedom of education, ${ }^{7}$ is not concerned with the quality of education, but instead approaches education as an object of contention between different dramatis personae (primarily the state, the parents, and the churches) and regulates who, in case of possible conflict, may do what: determine the school curriculum, decide about religious instruction, establish private schools, or the like. The Constitution thus divides up the territory, which then is left to the schemes of those to whom it has been allotted. ${ }^{8}$ Socialists

${ }^{5}$ According to the West German Constitutional Court, legislation which authorizes administrative activity potentially affecting a citizen's rights must also specify which administrative body the citizen can sue if he should feel aggrieved, since an unenforceable right would be useless as a weapon. See Judgment of April 9, 1975, BVerfG, W. Ger., 39 Entscheidungen des Bundesverfassungsgerichts [BVerfGE] 276, 301.

- See Ossenbühl, Die Interpretation der Grundrechte in der Rechtsprechung des Bundesverfassungsgerichts, 29 NeUE JURistische WochenschrifT [NJW] 2100, 2101 (1976).

7 GRUNDGesetz [GG] art. 7 (W. Ger.).

8 Since the Constitution is meant to ensure freedom, not accuracy of choice, it provides no precepts for the substantive use of autonomy, but only for its limits. For example, the Federal Constitutional Court was able, on the same day, to sanction both religiously and secularly oriented curricula in state schools: refusing to side with either atheists or believers, the Court focused on the question whether curriculum decisions had been reached in an 
would criticize this bourgeois preoccupation with individual autonomy (rather than with the supply of substantive goods) as empty and formal: freedom of choice might well be useless in the presence of poverty or ignorance. But bourgeois rights, as entitlements, are to be taken seriously and must therefore be limited; only limited promises can be kept. If a bourgeois constitution were to grant its citizens a right to be educated, rather than simply to have equal and unhindered access to existing educational facilities, that right would soon degenerate into mere program and thus lose its crucial quality of being a weapon.?

Socialist rights are not primarily entitlements, but policy declarations. Instead of protecting individual autonomy, they set public standards for desirable goals and behavior. Socialist rights are thus not weapons (which would imply potential hostility between the individual and society) but rather like railroad tickets: they entitle the holder only to travel in the indicated direction. The enforceability of a right is always dependent upon its underlying policy justifications. ${ }^{10}$ To use again constitutional rights as an example: East German constitutional rights do not protect individual self-determination are are in fact not enforceable at all. To the extent that East German authors ever deal with the issue of constitutional guarantees, they prefer to see basic rights as a horizontal affair, concerning the relationship between citizen and citizen rather than the relationship between citizen and state. The consti-

adequately democratic fashion and whether they left sufficient room for the exercise of opposite convictions. Compare Judgment of Dec. 17, 1975, BVerfG, W. Ger., 41 BVerfGE 29, 3953 (denying a challenge by atheistic parents to a state law providing for the allocation of teaching positions by religious sect, allowing time during school hours for religious instruction, and requiring teacher training programs to provide religious instruction courses) with Judgment of Dec. 17, 1975, BVerfG, W. Ger., 41 BVerfGE 88, 95, 108-16 (denying a challenge by religious parents to a state law providing for three school classifications-sectarian, general religious culture, and ethical-and permitting reclassification according to the wishes of a certain percentage of parents).

- The Federal Constitutional Court acknowledged (though with obvious regret) the substantive limitations of bourgeois constitutional rights in its numerus clausus decision of July 18,1972 , in which the Court rejected claims by prospective medical students demanding admission to a university even if the number of applicants exceeded the number of available places. In the Court's words: "[A]n individual's positive claim on society [here, to the right to study a particular subject] can exist only under the condition of what is actually possible. This will have to be determined by the legislature under its own responsibility . . . ." Judgment of July 18, 1972, BVerfG, W. Ger., 33 BVerfGE 303, 333.

1 Cf. Büchner-Uhder, Poppe \& Schüsseler, Probleme und Aufgaben bei der Erforschung und Verwirklichung der Grundrechte und Grundpflichten der Bürger in der Deutschen Demokratischen Republik beim umfassenden Aufbau des Sozialismus, in Demokratie UND GRUNDRECHTE 52 (1967) ("[Basic rights] are never rights to withdraw from society . . . [T] There is absolutely no room for separating in whatever fashion the concept of rights from its social purpose."). 
tutional protection of personal property, ${ }^{11}$ in this view, would be threatened by thieves rather than by government interference. Accordingly, personal property is protected by a criminal policy of vigorously prosecuting theft, and the protection of law and order in general is seen as a "guarantee" of constitutional rights. ${ }^{12}$

But the fact that an East German citizen cannot pursue his constitutional rights by suing the state does not necessarily make those rights meaningless. To take the right to education: the GDR Constitution does not promise freedom of education, but instead describes in detail a model socialist education. ${ }^{13} \mathrm{~A}$ citizen has no right to an education outside this model, not even to an education conforming to this model, but the constitution does promise that the state will follow an educational policy that aims at a socialist education for all. While not enforceable in court, this policy pronouncement will have indirect legal significance in the form of court decisions favoring people who pursue a socialist education or disfavoring people who do not, as, for instance, in child custody awards. ${ }^{14}$ Similarly the constitutional "right to work" 15 does not entitle a citizen to sue the state for employment, but it does-as a policy pronouncement-find reflection in court decisions that protect employment and people who work ${ }^{16}$ or in decisions that discriminate against people who do not work. ${ }^{17}$

Socialist constitutional rights are thus as weighty as the policy they are designed to express. In the case of traditional civil rights like free speech, ${ }^{18}$ which rank low in the socialist hierarchy of values and actually run counter to important organizational principles

"Die Verfassung der DDR [VERF.DDR] art. 11, para. 1 (E. Ger.).

12 See U. Dähn, J. Renneberg \& H. Weber, Kriminalitatsbekampfung und die Rechte der Burger im Sozialismus, 26 StaAt und Recht [StuR] 117, 120-23 (1977); R. ARLt \& G. Stiller, ENTwicklung DER SOZLALISTISChEN RECHTSORDNUNG IN DER DDR 211, 215 (1973).

13 VERF.DDR arts. 25 \& 26 outline the substantive essentials of socialist education: compulsory 10-year schooling, polytechnical education, special schools for the handicapped, prerequisites for university admission, and freedom from tuition.

"See Judgment of Feb. 2, 1971, OG, E. Ger., 25 NeUE JUSTIZ [NJ] 405, 406 (1971) (fact that a 3-year old child was raised predominantly by its father will not prejudice the mother's custody claim if she spent most of the child's life at a university in a different town in order to exercise her "basic right" to an education).

15 VERF.DDR art. 24, para. 1.

" See, e.g., Judgment of June 18, 1971, Stadtgericht von Gross-Berlin, E. Ger., 27 ARBErT UND ARBETTSRECHT [AUAR] 221, 222-23 (1972) (dispute over employee's dismissal); Judgment of May 7, 1974, OG, E. Ger., 29 NJ 23, 25 (1975) (child custody decision favoring working parent).

${ }^{17}$ This is done primarily through the denial of alimony to non-working wives after divorce, often regardless of the presence of small children. See Judgment of Sept. 8, 1958, OG, E. Ger., 13 NJ 248, 249 (1959); Judgment of Dec. 2, 1975, OG, E. Ger., 30 NJ 113,114 (1976).

18 VERF.DDR art. 27. 
such as democratic centralism, the constitutional pronouncement of a "right" will be unsupported by any political corroboration and will thus be worthless. In the case of rights like the right to education or to work, which always have figured in Marxist ideological history and are in line with present-day political requirements, the constitutional right will be sustained by actual policy and will thus have meaning. As political guidelines, however, constitutional rights will not only legitimate benefits but also justify interference: while "the right to work" protects employment, its alter ego, the "duty to work," 19 helps to enforce it. Socialist constitutional rights thus not only do not ward off state intrusion, but, on the contrary, facilitate it by serving as a funnel through which official standards can be infused into individual lives.

\section{B. Differences in Focus}

Bourgeois law focuses on the end result of a right's realization in court; socialist law focuses on the process of involvement and information retrieval preceding the realization of a right.

The second major difference between bourgeois and socialist rights follows from the first. As entitlements, bourgeois rights are geared toward enforcement, if necessary through litigation. Bourgeois law thus focuses on the outcome of a dispute, on what an individual will get from the law, on his day in court. The law is result-oriented; like Shylock, it insists on its pound of flesh. This emphasis on the personal benefits derived from the law also implies an acceptance of confrontation and social isolation: the bourgeois rightholder is protected as an egotist; as bourgeois; not as citoyen.

A good example is the citizen's protection against the executive in West German administrative law. Access to court in order to contest administrative acts is granted generously and exhaustively. The Basic Law, in article 19, paragraph 4, aims at "as gapless a system of review as possible" ${ }^{20}$ in order to protect the individual

" Compare VERF.DDR art. 24, para. 1, with VERF.DDR art. 24, para. 2 ("The right to work and the duty to work are inseparable.").

20 Judgment of Nov. 12, 1958, BVerfG, W. Ger., 8 BVerfGE 274, 326. With the constitutional exception of wiretaps, GG art. 19, para. $4 \&$ art. 10, para. 2, which are reviewed by a special parliamentary committee, Gesetz zur Beschrankung des Brief-, Post- und Fernmeldegeheimnisses (law concerning restriction of right to secrecy in communications media) of August 13, 1968, $\S 9$, [1968] Bundesgesetzblatt [BGB] I 951 (W. Ger.), upheld in Judgment of Dec. 15, 1970, BVerfG, W. Ger., 30 BVerfGE 1, 3, 26-31, and the disputed exception of pardons, compare Judgment of April 23, 1969, BVerfG, W. Ger., 25 BVerfGE 352, 358-63 (pardons not reviewable in court under federal constitution) with Judgment of Nov. 28, 1973, Hessischer Staatsgerichtshof, W. Ger., 27 Die Öfentliche Verwaltung 128, 129-30 (pardons reviewable in court under state constitution) and E. EyermanN \& L. FoHLER, Verwaltungs- 
from encroachments by public authority. But court protection is limited to the defense of strictly personal rights. West German administrative law accepts neither abstract review (that is, judicial review of legislation which has not yet, through its application, come into conflict with individual rights), ${ }^{21}$ nor so-called "popular" actions (Popularklagen) in the service of other than personal interests. $^{22}$ Public concerns find administrative court protection only if they can be legally disguised as private complaints. Sometimes-as illustrated by the present wave of suits in West German administrative courts against the construction of nuclear reactors-the adjudication of public policy issues can indeed be had under the mantle of private property or health rights. More often, public interests will be seen as too peripherally related to the legal rights of specific individuals to warrant court inspection (as in many pollution or urban planning matters). Bourgeois judicial review is clearly geared toward individual protection, not toward social control. The device of standing ensures that protection will go to those in most immediate need of it, but it does so at the expense of civic involvement. Chacun pour soi, Dieu pour nous tous. Until recently, furthermore, the civic abstinence built into West German administrative court procedure was reinforced by an almost total disregard for a citizen's views and possible objections during the administrative process itself: why give the addressee of an administrative act the right to a hearing or to access to the record at this early stage, if once the act becomes effective he will still be entitled to his day in court? ${ }^{23} \mathrm{New}$ legislation has now introduced a certain measure of citizen participation into the preparatory stages of administrative decisionmaking. ${ }^{24}$ But even this participation serves primarily the better

GERICHTSORDNUNG $§ 42 \mathrm{n.37a}$ (6th ed. 1974), every administrative act or omission which violates a citizen's rights can be contested in court. $C f$. Verwaltungsgerichtsordnung (administrative court act) of Jan. 21, 1960 [VwGO], \$ 40, [1960] BGBl I 21-22 (W. Ger.) ("Access to administrative courts is given in all public law disputes not involving constitutional questions insofar as the disputes are not expressly assigned to another court by federal law.").

21 There are a few exceptions. For instance, see the "abstract" review of zoning ordinances possible under VwGO, $\S 47$, supra note 20 .

22 Suggestions for introducing class-action suits into West German law have not as of now led to effective legislative efforts in that direction. Rehbinder, Argumente für die Verbandsklage im Umweltrecht, 9 ZEITSChRIFT FÜR RECHTSPOLITIK 157 (1976); Bender, Die Verbandsklage, 92 Deutsches VerwaltungsblatT 169 (1977).

23 See F. Scharpf, Die politischen Kosten des Rechtsstaats 38-39 (1970).

21 The Verwaltungsverfahrensgesetz (administrative procedure act) of May 25, 1976, [1976] GBGl I 1253 (W. Ger.), has now granted a general right to be heard ( $\$ 28$ ) and to have access to the record $(\$ 29)$ to the addressee of a planned administrative act. These rights had previously been granted only occasionally in legislation dealing with particular types of administrative decisions. For new civic participation in planning and zoning decisions, see 
protection of a citizen's private rights; ${ }^{25}$ while approaching a citizen as slightly less passive than it did before, West German administrative law still views him primarily as a self-centered guardian of personal interests.

Socialist law, on the other hand, is much less concerned with the final outcome of an individual complaint than with the events preceding that outcome: the discovery of weak spots in the social system; the lessons to be learned from a particular grievance (for instance a housing complaint) about the best ways to overcome general administrative shortcomings (for instance, ineffective organization, bureaucratic insensitivity, corruption); the cooperation and information-exchange between all state bodies involved in the handling of a particular issue; the education and indoctrination of the participants. This attitude follows again from the socialist understanding of rights as policy pronouncements: for the success of the policy embodied in the right, the participation and cooperation of all actors involved in a particular dispute will be much more important than the fate of the right itself. Accordingly, while bourgeois law focuses on a right as an end, socialist law focuses on a right as a means by which a useful social process can be set in motion.

Again, the citizen's protection against the executive can serve as an example. Whereas West German administrative court procedure carefully restricts standing to the defense of a plaintiff's individual rights but provides considerable means of pressure once standing has been granted, East German complaint mechanisms do not require a complainant to be personally affected by the contested decision, ${ }^{26}$ but are without any procedural bite. Restrictions on a citizen's "standing" would only discourage civic involvement and would suppress valuable information about bureaucratic shortcomings. Granting an individual the right to enforce a particular result, on the other hand, would seriously confine the administra-

Bundesbaugesetz (federal land use planning and zoning statute) of Aug. 18, 1976 [BBauG], [1976] BGBl I 2257 (W. Ger.).

${ }^{25}$ An exception may be the new procedure for "early citizen involvement" in land use planning. See BBauG, $\$ 2 \mathrm{a}(2)$, id. Section $2 \mathrm{a}(2)$ seems aimed not so much at a strengthening of individual legal positions as at an overall improvement in the rationality and sensitivity of local zoning decisions.

2 An insignificant exception is found in the formal administrative complaint procedure according to the Gesetz über die Neufassung von Regelungen über Rechtsmittel gegen Entscheidungen staatlicher Organe (statute on the uniform regulation of formal administrative complaints) of June 24, 1971 [RechtsmittelG], [1971] GBl.DDR I 49 (E. Ger.), that presuppose a violation of an individual right of the complainant. However, since this procedure is as devoid of procedural bite as the informal petition procedure, which requires no personal interest on the side of the complainant, the requirement is practically meaningless. 
tion's ability to deal with the problem at hand as it sees fit. For these reasons, East German law rejects the notion of judicial review, and indeed of all non-administrative controls over bureaucratic decision-making. ${ }^{27}$ The East German citizen who wants to object to administrative behavior finds a number of avenues open to him: formal administrative complaints, ${ }^{28}$ informal petitions, ${ }^{29}$ applications for compensation for tortious acts by the government, ${ }^{30} \mathrm{com}$ plaints to the Procuracy ${ }^{31}$ or to the Workers-and-PeasantsInspection. ${ }^{32}$ All these procedures are easily accessible and contain rules designed to ensure that the information received will be carefully registered and processed. Some invite the citizen to participate in collective efforts to correct shortcomings and prevent future deviations. None, however, furnishes any means of procedural pressure beyond repeated complaints. Under socialism, investigations into administrative legality serve primarily not to protect individual rights, but to ensure the proper functioning of the bureaucracy.

\section{Precision of Definition}

Bourgeois law aims at exact definitions of rights; socialist law intentionally blurs definitions of rights.

The third major difference between the bourgeois and socialist approach to rights is closely connected with the differences previously listed. Bourgeois law, which views rights as entitlements to be enforced in court, must know exactly how much a citizen is entitled to in each individual case. While obviously no legal system could function without a certain amount of vagueness and open texture, bourgeois jurists nevertheless try to limit that vagueness

27 The East German parliamentary complaint committees were short-lived exceptions to this practice. Introduced by the Erlass des Staatsrates der DDR über die Bearbeitung der Eingaben der Bürger (decree regarding handling of citizen petitions) of Nov. 20, 1969, [1969] GBI.DDR I 239 (E. Ger.), they were dropped without mention in the Eingabengesetz (statute on petitions) of June 19, 1975 [EingabenG], [1975] GBI.DDR I 461 (E. Ger.). The complaint committees, which were attached to the local legislative bodies, had no decision-making powers of their own, but could bring administrative illegalities to the attention of the legislatures and their respective executive councils. The committees' abolition must have caused some official embarrassment since it was never commented on in the press.

2x RechtsmittelG, supra note 26.

20 EingabenG, supra note 27.

${ }^{30}$ Staatshaftungsgesetz (government tort liability act) of May 12, 1969, [1969] GBI.DDR I 34 (E. Ger.).

" Gesetz über die Staatsanwaltschaft der DDR (statute on the procuracy) of April 7, 1977, § 4(2), [1977] GBI.DDR I 94 (E. Ger.).

32 Beschluss des Zentralkomitees der Sozialistischen Einheitspartei Deutschlands und des Ministerrates der DDR über die Arbeiter-und-Bauern-Inspektion der DDR (decree of the Central Committee and the Council of Ministers on worker-and-peasant-inspection) of August $6,1974, \S 1(\mathrm{e}),[1974]$ GBI.DDR 390 (E. Ger.). 
as much as possible and attack ambiguity with fine qualifications and minute distinctions the moment they perceive it. Because bourgeois rights convey autonomy to the right holder, they need exact demarcations: good fences make good neighbors. The West German approach to workers' participation can serve as an example. West German law perceives "codetermination" as powersharing between capital and labor, and attempts to define accurately the exact shares of each group. The law therefore carefully counts the number of votes allotted to capital or labor in relation to decisions made by the board of directors, ${ }^{33}$ and it devises complicated procedures to ensure the neutrality of odd members on panels otherwise evenly composed of representatives of both sides (for example, for the election of the eleventh man to the board of directors in the coal and steel industry ${ }^{34}$ or of the neutral man to the works conciliation board ${ }^{35}$ ). And since co-determination is based on the notion of conflict between labor and capital-conflict which cooperation mechanisms may contain and make fruitful, but which nevertheless may erupt into battle-the front lines between the opponents must be precisely drawn. Hence unions must be independent of outside influences in order to enjoy union status, ${ }^{38}$ and organizations that count non-employees among their members are excluded from union privileges. ${ }^{37}$

Socialist law, on the other hand, often blurs the exact contours of a right. Again this follows from the fact that socialist rights are policy pronouncements, and that the law puts greater emphasis on the realization of that policy than of the right itself. Exact definitions protect a rightholder: they not only tell him what he is entitled to do, but also what others (including the state) are not entitled to do. Bourgeois insistence on precision thus limits policy interference. Socialist vagueness facilitates it. The much-used phrase "unity of right and duty,"38 which confuses the borderlines of a right

3see Montan-Mitbestimmungsgesetz (act on labor-management codetermination in the coal and steel industry) of May 21, 1951 [MontanMitbestG], $\& 4$, [1951] BGBl I 348 (W. Ger.) (board of directors representation in coal and steel industry); Mitbestimmungsgesetz (codetermination act) of May 4, 1976, § 7, [1976] BGBl I 1155 (W. Ger.) (board of directors representation in other industrial enterprises with more than 2000 employees); Betriebsverfassungsgesetz (works constitution act) of Oct. 11, 1952, § 76, [1952] BGBl I 691 (W. Ger.) (board of directors representation in industries other than coal and steel with fewer than 2000 employees).

अ MontanMitbestG $\S 8(1)$, supra note 33 .

2s Betriebsverfassungsgesetz (works constitution act) of Jan. 15, 1972, §76(2), [1972] BGBI I 27-28 (W. Ger.).

st Judgment of Nov. 18, 1954, BVerfG, W. Ger., 4 BVerfGE 96, 107.

37 Judgment of Nov. 23, 1962, BVerwG, W. Ger., 15 Entscheidungen des Bundesverwaltungsgerichts $168,172$.

3* E.g., right and obligation to participate in civic affairs (VERF.DDR art. 21, paras. 1 \& 3), right and duty to work (VERP.DDR art. 24, paras. 1 \& 2), right and duty to educate one's children (VERr.DDR art. 38, para. 4). The principle of the "unity of right and duty" suppos- 
and thus the degree of autonomy it confers, is a good example of the intentional fuzziness of socialist rights.

So, too, is the East German approach to workers' participation. The GDR Labor Code of 1961 listed the participation rights of the enterprise union organization in largely non-technical terms (such as "consent," "approve," "agree," "cooperate with," "hearing the opinion of," and "in conjunction with"), and did not specify whether violations of participation rights affected the validity of management decisions..$^{39}$ East German case law ${ }^{40}$ and the new Labor Code of $1977^{41}$ have since eliminated some of the confusion. But the functions of union organizations themselves remain blurred: unions are at the same time interest representatives and support organizations for the management. The notion of what constitutes workers' participation is blurred: it includes participation in enterprise affairs as well as "socialist competition" (for instance, campaigns to increase performance) and the solution of tasks on the workers' own time (for instance, innovation agreements). The individual worker's obligations towards his employer are blurred: they require him not only to perform his work duties but to maintain certain moral standards, so that the violation of civic (not just labor) duties can lead to a loss of the worker's right to the annual bonus which ordinarily forms part of his salary. ${ }^{42}$ While West German labor law seeks to increase individual autonomy by extending the employee's influence over the work process, East German labor law seeks to increase

edly extends to other areas of law as well. For the area of civil law see, e.g., Reinwarth, Das Prinzip der Einheit von Rechten und Pflichten im Zivilgesetzbuch, 30 NJ 89 (1976).

${ }^{3}$ See Gesetzbuch der Arbeit der DDR (labor code) of April 12, 1961, [GBA] §§ 8-19, [1961] GBl.DDR I 30-32 (E. Ger.). The one exception has been union consent to dismissals, which very early cases established as a prerequisite for a valid dismissal. See Judgment of May 23, 1955, OG, E. Ger., 1 Entscheidungen des Obersten Gerichts in Arbeits- und Sozialversicherungssachen [OGA] 131, 131; Judgment of Dec. 15, 1955, OG, E. Ger., 1 OGA 163, 166; Judgment of Jan. 7, 1957, OG, E. Ger., 2 OGA 74, 76.

so See Judgment of July 14, 1970, Bezirksgericht Karl-Marx-Stadt, E. Ger., 26 AuAR 636, 638 (1971) "“agreement" between management and enterprise union organization on the award or denial of premiums, as required by GBA, $\S 47$, supra note 39 , is a prerequisite to a valid premium decision); Judgment of Dec. 10, 1971, OG, E. Ger., 27 AuAR 286, 287 (1972) (requirement in GBA $\S 45$, supra note 39 , of the enterprise union organization's "consent" to manager's determination of wage categories means explicit consent by the union leadership collective prior to manager's decision).

"AGB, supra note 3. For example, union participation during the preparatory planning stages is now enhanced by the union organization's right to complain about the rejection of their plan suggestions to the next higher administrative or economic body (id. $\$ 7$ ); if a managerial decision requires "consent" of the enterprise union organization, that consent is now always a prerequisite for the validity of the manager's decision (id. $\$ 24$ para. 3 ).

2 Judgment of Dec. 23, 1974, Stadtgericht der Hauptstadt der DDR, E. Ger., 31 AuAR 63 (1976). 
the employee's dependency by extending the influence of the work ethic into his personal life.

\section{The Exercise of Rights}

Bourgeois law sees the exercise or violation of a right as a private affair; socialist law sees the exercise or violation of a right as a public affair.

Bourgeois rights, as entitlements, are generally left to the disposition of their owner; the enforcement of a right is a personal concern. A bourgeois legal system might assist a right-carrier who is too weak to assert his own interests (with the help of legal aid); it might encourage the pursuit of a claim by raising the stakes (for instance, by treble damage awards) or by lowering the costs (for instance, by the award of attorney's fees). But even in these cases the interest at stake is perceived as a personal interest. If the public is involved in the enforcement of a right (as it is through the participation of laymen or through the publicity of court sessions), it is not because of legitimate public interest in the proceedings, but because public involvement is meant to check the exercise of state power. We therefore exclude the public in situations where the individual need for privacy is greater than the public need for control (as in trials of juveniles or in West German divorce proceedings).

Socialist law, which views rights as policy pronouncements, sees the violation of a right as a threat to the policy in question and therefore as a social affair, in need of a social solution. Socialist procedure knows many forms of public participation: social representatives, who comment on the parties' personal character or circumstances; social defenders or accusers, who represent the view of the work collective in criminal proceedings; ${ }^{43}$ visiting sessions held at the locale-a factory or school, for instance-of a particular dispute or offense; court invitations to an "organized public" that is especially affected by the issue before the court. ${ }^{44}$ In all these instan-

"3 Strafprozessordnung [StP0] $\$ 54$ (Ministerium der Justiz ed. 1968) (E. Ger.). The fact that the number of social accusers exceeds the number of social defenders by more than three to one underscores the public purposes of this institution and betrays official prodding in the choice of collective representatives. Obviously, their primary purpose is not to bolster the position of the individual accused, but to bring home more effectively the moral lessons of the trial itself. See Statistisches Jahrbuch 1972 Der Deutschen Demokratischen Repubuik 488 (1972) for the year 1970 (the last year for which figures were published). Social accusers participated in 9,259 or $21.3 \%$ of the cases of persons whose trials ended in a sentence; social defenders in 2,742 or $6.3 \%$ of the cases.

"A good example of "organized publicity" is proceedings against people repeatedly defaulting in the payment of their rent, to which other, similarly obstinate rent debtors are invited. See Resolution of the Plenum of the Supreme Court of Dec. 15, 1971-1 PIB 1/71, 26 NJ Beilage (supplement) no. 2, at 3 (1972). 
ces, representatives of the public participate in the proceedings not because they should supervise the activities of the court, but rather because they are part of the social setting in which the conflict arose and therefore should be included in its solution. An individual conflict can in this fashion be transformed into a socialist morality play that educates and involves both immediate actors and spectators. Civic participation, under these circumstances, does not appear as the public's right to monitor the exercise of state power, but as the state's prerogative to broaden the impact of a useful indoctrination process to affect not only the individual citizen before a court, but also the collective in which he works or lives..$^{45}$ If, as recently has been the case, certain forms of social participation are restricted, ${ }^{48}$ these restrictions are seen neither as a cutting back on the rights of the collective nor as an increase in the protection of privacy of an individual in court, but simply as practical changes in procedural techniques, warranted by the unproductivity of participation for participation's sake, ${ }^{47}$ or by financial concerns. ${ }^{48}$

Beyond the adjudication of a particular conflict in court, socialist law knows a number of devices to keep society involved in the issue at stake. The court itself is supposed to criticize administrative shortcomings that come to light in the course of its proceedings ("court censure") or to follow up on the consequences of its decision-for instance, by investigating whether a couple that has been denied a divorce is handling its problems, and, if necessary, by coordinating state efforts to help. ${ }^{49}$ The collective can be brought into the rehabilitation of an offender through the institution of "sur-

${ }^{45}$ One case of pedagogical overreaching, even by socialist standards, is the decision of a district court which rejected the divorce suit of a mechanic "in order to educationally impress other mechanics [on the site] who live[d] separated from their families." See Ehescheidungen unter die Lupe genommen, 17 DER Schofre 61, 63 (1970)(criticism of this decision in the report to the February, 1970 Plenum of the Bezirksgericht Halle).

ts See, e.g., Gesetz zur Anderung der STPO der DDR (act amending the code of criminal procedure) of Dec. 19, 1974 [St PÄndG], § 102(3), [1974] GBI.DDR I 598 (E. Ger.) (restricting the participation of collectives in criminal trials).

${ }^{17}$ See Willamowski, Ziele und Grundfragen der Änderungen der StPO, 22 DER ScHöFFE 109, 111 (1975).

* See Informationsbericht des Präsidenten des Obersten Gerichts an das Präsidium des Bundesvorstands des FDGB über die Arbeitsrechtsprechung und die sich daraus ergebenden Schlussfolgerungen für die Zusammenarbeit zwischen den Gerichten und den Gewerkschaften zur Gewährleistung einer hohen Rechtssicherheit (Auszug), 26 NJ 373, 377 (1972), on visiting sessions in enterprises: "We think it is important that measures to increase the effectiveness of court activity, such as meetings in factories, do not distract the workers from their production tasks and thus result in economic losses."

"For a particularly impressive, and probably rare, example of such judicial post. operative help see Judgment of Nov. 11, 1963, Bezirksgericht Halle, E. Ger., 11 DER SchörFE 251, 253-54 (1964). 
ety of the collective." ${ }^{150} \mathrm{~A}$ court decision of general significance and educational value can be reported and analysed before a culprit's apartment block neighbors or his work collective. In practice, many of these mechanisms for collective involvement are, by socialist standards, underutilized, ${ }^{51}$ and courts repeatedly must be admonished to "properly locate the solution of an individual conflict within the context of overall societal development, to recognize the general within the specific, and to inquire into the origins of a conflict . . . ."52 Such criticism reaffirms, however, that socialist law sees the violation of an individual right as evidence of an underlying social ill and, at least ideally, attempts to cure the ill itself, not just the symptoms it produces.

\section{The View of LAw Under the Two Systems}

To summarize my comparison up to this point: Bourgeois law sees rights as individual entitlements, focuses on the end result of a right's realization (if necessary in court), insists on exact definitions (in order to know how much a rightholder is entitled to), and basically perceives the realization of a right as a private affair. Socialist law sees rights primarily as policy pronouncements; focuses on the process of realizing the policy more than on the eventual realization of the right itself; is interested in ambiguity (which facilitates the manipulation of a right for policy purposes); and basically perceives the realization of a right as a social affair.

The bourgeois and socialist approaches to law thus seem to differ primarily in their understanding of the relationship between the concepts of "law" and "right" - that is, between the body of rules sanctioned by a particular political system, and the benefits that an individual derives from these rules. A bourgeois jurist tends to approach law in terms of the rights it protects: faced with the task

30 See $\S 57$ StrafprozeBordnung (Code of Criminal Procedure) of Jan 12, 1968, GBI. DDR I 49, in the version of StPAndG of Dec. 19, 1974, supra note 46 . In return for a collective pledge to supervise and guarantee their colleague's rehabilitation, a sacialist judge can suspend a sentence or replace a prison sentence with another form of penalty.

s1 For instance, visiting court sessions at the location of a particular conflict are "numerically insignificant," (Toeplitz, Erste Schlussfolgerungen für die Rechtsprechung aus dem IX. Parteitag der SED, $30 \mathrm{NJ} 409,410-11$ (1976); court censure is used in 3\% of all labor law proceedings (and probably less in other proceedings), (Heintze, Arbeiterklasse, Gewerkschaften und Sozialistisches Recht, $27 \mathrm{NJ} 219,221$ (1973)); collective evaluation of court decisions in enterprises takes place with respect to $7.6 \%$ of all labor law decisions (id.); the number of follow-up investigations by courts in criminal cases is "still unsatisfactory." Plenartagung des Obersten Gerichts zu Problemen der Wirksamkeit des Strafverfahrens, 28 NJ 447, 451 (1974).

32 Zu Problemen der Ehröhung der gesellschaftlichen Wirksamkeit der Tätigkeit der Bezirks- und Kreisgerichte auf dem Gebiet des Zivil-, Familien-, Arbeits- und LPG-Rechts: Bericht des Präsidiums an das Plenum des Obersten Gerichts auf der 30. Plenartagung am 24. Marz 1971, 25 NJ 258, 261 (1971). 
of solving a legal conflict, he will dissect the issue into the rights of the parties involved and then weigh those rights against each other. He will apply this technique not only to conflicts between parties of equal position and power (as in contract or property disputes), but also to conflicts involving greatly disparate opponents (for instance, the battle between prosecution and defense counsel, or the conflict between the unborn's right to life and the mother's right to determine what happens to her body). We expect from law the protection of what is our due. Hence the bourgeois fascination with procedure: since we understand a legal conflict as a match of right pitted against right, with both potentially of equal weight, we have to see to it that the rules of the match are impartial. Bourgeois law is basically a horizontal affair: it coordinates purposes, balances interests. Our figure of justice is blindfolded and holds a scale-a neutral arbiter of rights.

In the socialist view, the bourgeois preoccupation with individual benefits veils and distorts the political character of all law. Law is important not because it confers rights but because it prescribes the behavior necessary to progress on the path to socialism. Rights as policy pronouncements are individualized means of conveying the commands of the law. To a socialist, our relationship between law and rights thus should be reversed. He does not look at law as the container of rights, but at rights as the embodiment of law. $\mathrm{He}$ is less interested in procedure (to him, our insistence on neutrality reeks of social agnosticism) than in substance. Rather than balancing right against right, a socialist will look for the policies embedded in particular rights, then rank them according to their importance and urgency. We try, or pretend to be, neutral; socialists try, or pretend to be, partial-not to the parties to a dispute, but to the Party as the authoritative guide towards social progress. We want to be fair; socialists want to be correct. Law under socialism is a vertical affair: order, direction, discipline, command. A socialist figure of justice would not be blindfolded, but seeing, and she would show the way with outstretched arm and pointing finger.

\section{InCONSISTEncies aNd Conflicts Within the Socialist} APPROACH TO LAW

The socialist understanding of rights as policy statements, and the resulting view of law as a set of commands rather than a vehicle for entitlements, appears to square well with the socialist concept of law as an instrument of change. To quote Erich Honecker at the Ninth Party Congress held in 1976: "The law is a remarkable means 
for the exercise of power." approach to law seem to put the socialist legal system under considerable stress and may not only threaten the usefulness of law as a political tool, but eventually lead to a redefinition of rights.

One source of tension within a socialist legal system is its conscious use of ambiguity: what I have described earlier as the "blurring" of individual rights. Since socialist rights are policy pronouncements rather than entitlements, their borders should not be defined too precisely lest the rightholder use his right as an enclave to withdraw from society (personal property could serve as an example). In order to allow the infusion of policy concerns into a relationship involving rights, socialist law thus keeps rights ambiguous, blends rights with obligations, and blurs the areas of a right's applicability. This need for inexactness as a means of preventing confrontation between rightholders and society is at odds with a simultaneous need for exactness stemming from the fact that socialist law is seen primarily as command.

To be effective, a command must be precise, particularly in a highly planned and centralized state that mistrusts all uncontrolled delegation of authority. Precision, on the other hand, allows the recipient of a command to draw distinctions, to make excuses, and possibly to question the applicability of the command to his individual case. Precision protects: clearly defined rights become less penetrable to the policy considerations that are meant to justify their existence in the first place. Precision therefore appears as both a prerequisite for and a threat to the usefulness of a right as a means of political guidance. The socialist approach to law thus produces a dilemma: socialist law wants to be exactly obeyed, but it does not want to be taken at its word.

A second more basic deficiency of the socialist command-view of law seems to be its built-in disregard for individual interests. Socialist law protects rights not out of respect for individual autonomy, but because the policy values embodied in a particular right deserve realization. As a result, socialist legal systems tend to be insensitive to the private needs of a rightholder. They often fail to furnish procedures with sufficient teeth to allow a citizen to push effectively for his rights (as in constitutional and administrative law), or they convey insufficient autonomy to make the exercise of a right attractive to its holder (as in economic or civil law). In a legal system in which law appears above all as command, the use of law loses attraction.

${ }^{33}$ Neues Deutschland, May 19, 1976, at 3, col. 11. 
Accordingly, there are many complaints in the East German literature that state-owned enterprises and individual citizens make insufficient use of the law. Litigation rates are notoriously low; ${ }^{54}$ contract damages are not sought, and penalties not enforced;55 leases are not drawn $u^{56}$ and rents not paid. ${ }^{57}$ Enterprise damage claims against employees are often raised too late ${ }^{58}$ or eventually dropped. ${ }^{59}$ Participation rights of union organizations are disregarded, ${ }^{60}$ and citizens fail to assert their legal claims against stateowned stores. ${ }^{61}$ In a bourgeois legal system such attitudes would cause alarm only to the extent that the failure to assert rights might be due to the rightholder's social weakness or ineptness, which would mean that his autonomy-and consequently the functioning of our model of law as a mechanism for interest coordination-would be put into question. Barring such social imbalance, we can assume that the rightholder knows his own interests best and can leave the use or non-use of the right to his own discretion. But in a socialist legal system, where rights are enforced for policy's sake, the non-assertion of a right cannot be a matter of social indifference, since it implies disregard for the Party's commands embodied in that right. If law is perceived not as a mechanism for the balancing of interests but as a kind of historical blueprint designed by the Party, it must be carried out if construction is to proceed according to schedule. For this reason, all socialist legal systems put great emphasis on what is called "law-implementation"

st See Blankenburg, Studying the Frequency of Civil Litigation in Germany, 9 LAw \& Soc'y REv. 307 (1975).

ss See Heuer, Vertragsdisziplin und Gesetzlichkeit, 30 EinHErT 637 (1975). Although economic contracts are to be concluded early enough to be incorporated into the plan proposals for the upcoming year, it is not unusual that a contract is proposed only after the plan has reached effect and the State Arbitration Tribunal in fact quite commonly adjudicates precontract disputes way into the planning year. Id. at 638 .

36 Mühlmann in: StAat, RECHT uNd DEMOKRATIE bEI der Gestaltung DER ENTwickelten sozialistischen Gesellschaft 208, 211 (1975) [hereinafter cited as StaAT, REcht UND DEMOKRATEE].

${ }^{77}$ Rent arrears in the GDR have risen from about 10 million marks in 1970 (Bericht des Prasidiums, $26 \mathrm{NJ} 35,36$ (1972)) to more than 16 million marks in 1973. Toeplitz, Die Aufgaben der Rechtsprechung der Gerichte im 25.Jahr der DDR, 28 NJ 381, 382-83 (1974).

s8 Strasberg, Schutz des sozialistischen Eigentums in Arbeits-, Zivil- und Familienrechtsverfahren, 27 NJ 639, 640 (1973).

59 See Resolution of June 19, 1974, Plenum des OG, E. Ger., 28 NJ 639, 640 (1973)(modifying legal effect of enterprises' waiver of rights to damages according to Guideline No.29 of March 25, 1970, Plenum des OG, [1970] GBl.DDR II 267 (E. Ger.)).

- Jolitz, Zur gewerkschaftlichen Mitgestaltung sozialistischer Arbeitsrechtsverhältnisse, 27 AUAR 380 (1972).

i Kellner, in StaAt, Recht und Demokratie, supra note 56, at 213, 215.

i See R. ARLT \& G. STILLER, supra note 12, at 169-92. 
the respectful observance and realization of all legal rules by all members of society.

However, the pedagogical methods used to instill the desired "state-and-law discipline" (Staats- und Rechtsdisziplin) in the addresses of the law are, once again, "vertical" methods: primarily exhortation, supervision, and disciplinary sanctions. A special field of socialist legal thinking, "legal propaganda," deals with the techniques and contents of indoctrination best suited to convince everyone of the necessity of observing the commands of the law.$^{63}$ State and economic functionaries are expected to practice "legal propaganda" actively through talks, meetings, discussion sessions, and the like, by means of which the demands of "socialist legality" are explained and disseminated. ${ }^{64} \mathrm{~A}$ sizeable popular literature on lawrelated questions serves the same purpose. Legal discipline is particularly stressed in the area of the economy, where it is feared that the disregard of legal regulations, including contracts, will upset the predictability and success of the Plan. Because of this concern, East Germany (like other socialist states) has passed a special decree "on the improvement of legal work in the economy," 65 which coordinates the efforts of different government bodies and economic organizations in supervising and analyzing the observance of legal rules. Legal counsel of state-owned enterprises are drawn into these programs - not to stress their clients' rights, but to supervise their clients' observance of "socialist legality." 66 In all these campaigns socialist law appears not as a body of rules that can be advantageously handled by the participants in the legal process, but as a set of commands to be religiously observed. The message is not "know your rights" but "know the law." It is hoped that knowledge

's On May 7, 1974 the Politbureau passed the (unpublished) Beschluss über die nächsten Aufgaben zur Erläuterung des sozialistischen Rechts sowie zur Festigung und weiteren Entwicklung des Rechtsbewusstseins der Werktätigen (resolution concerning the immediate tasks to explain the socialist law and to strengthen and further develop the legal consciousness of the toilers), which laid the ground for the ensuing legal propaganda activities in all areas of social life. On this Resolution see Grieger, Rechtserziehung und Rechtspropaganda, 22 Der Schöffe 177 (1975); K. Sorgenicht, StaAt, REChT und Demokratie NaCh DEM IX. Parteitag der SED 131 (1976).

4 See Streit, Auf dem bewahrten Kurs weiter voran! 30 NJ 345, 348 (1976) according to whose report in 1975 state attorneys, judges, and notaries alone held more than 90,000 meetings on legal topics and produced more than 10,000 legal propaganda articles for the media.

is Beschluss über die Verbesserung der Rechtarbeit in der Volkswirtschaft (resolution concerning the improvement of legal work in the economy) of June 13, 1974, [1974] GBI.DDR I 313 (E. Ger.).

"See id., art. III(3). Cf. Schirmer, Sozialistische Rechtserziehung, 23 DAS HOCHSCHULWESEN 130, 133 (1975)(on the role of socialist lawyers: "I see a jurist above all as a state functionary who-independent of his specific tasks-through his work enforces the decisions of the Party.") 
of the law's rules and understanding of its historical justification will then, in turn, generate compliance: "To be informed about the demands which the law makes upon his behavior will enable a citizen to comprehend the . . . unity of individual, state, and society . . . under socialism and to recognize his responsibilities."67

Socialist legal propaganda thus follows the socialist model of rights: it does not focus on the private insistence on one's due, but primarily on the observance of policy goals for society's sake. To treat rights as entitlements, and to regard the use of law as a weapon, would introduce a disruptive measure of autonomy and egotism into a system that stresses subservience to a commonly shared goal. To the extent that incentives are in fact used to stimulate observance of the law, they are not built into the legal system itself as in bourgeois law, which, by protecting areas of individual autonomy, encourages and rewards the clever handling of rules. Instead, incentives are introduced from outside, as rewards handed out by the state. Compliance with legal obligations thus will be one criterion for the evaluation of a socialist manager's performance. ${ }^{68}$ Observance of the law can also be rewarded through premiums: collectives fighting for the title "exemplary collective of order, discipline and security" will be judged in part on the basis of their demonstrated respect for legal rules. ${ }^{69}$ Evidence of the collective's deference to the law will be found in such facts as the absence of criminal convictions or of divorces among its members, regular payments of rent or child support obligations, and careful observance of work safety rules. To us, trained to look for the interests protected by a particular piece of legislation, this hodgepodge of very different legal obligations seems to lack conceptual coherence. But to a socialist, all legal rules express the will of the Party, and in their quality as commands they have a common denominator. ${ }^{70}$

The socialist state thus tries to respond to an apparent lack of interest in its legal system through intensified education and indoctrination campaigns. However, if $I$ am right in assuming that the

${ }^{67}$ Udke, in: Staat, Recht und Demokratie, supra note 56, at 315.

6x Verordnung über die Aufgaben, Rechte und Pflichten der volkseigenen Betriebe, Kombinate und VVB (decree on the tasks, rights, and duties of state owned enterprises, combinations, and enterprise associations) of March 28, 1973, \& 7, [1973] GBl.DDR I 130-31 (E. Ger.).

63 See Uschkamp, Aufgaben der örtlichen Organe bei der Verwirklichung von Gesetzlichkeit, Ordnung and Sicherheit, $28 \mathrm{NJ} 253,253-54$ (1974), on the criteria for successful competition.

${ }^{70}$ Cf. Kranke, Nutzen wir noch besser unser sozialistisches Recht! DIE ARBEIT, no. 11 at 11,12 (1974), on evaluation criteria for socialist competitions: "No contradictions can and may exist between a person's behavior at work and the other aspects of his life. Socialist morality, the attitude towards socialist legality, is indivisible." 
socialist public's disillusion with law is due to the system's equation of law and command, and to its reluctance to perceive rights as entitlements rather than individualized policy statements, these campaigns will have little chance of success. They basically amount to a treatment of "more of the same." The socialist legal system seems to suffer from the same problems that plague the socialist economic system: too much emphasis on command, an unwillingness to respect individual autonomy, insufficient incentives. One might even argue that socialism today misunderstands what law is all about. Pashukanis once proposed, in his General Theory of Law and Marxism, ${ }^{71}$ that all law is basically contract law because it serves to coordinate opposed interests. To serve this function it must first recognize the rights of isolated and autonomous individuals in order to balance them against each other. Even criminal law, according to Pashukanis, fits into this model, because it insists on the correct "price" for each offense and on procedures that ensure a proper bargain between offender and state. Socialism today has reversed this approach: all law is basically criminal law, ukaz. ${ }^{72}$ Indeed contracts are often enforced not because the interest constellation between the parties makes enforcement desirable, but because the state so orders. The Statute on State-Owned Enterprises, for instance, requires a manager to assert-and if need be, to enforce-all his enterprise's claims. ${ }^{73}$ As long as socialist law does not accept the oppositions and egotisms of the law's addressees, both in relation to each other and to the state, it cannot satisfactorily function as a mechanism of interest-coordination.

\section{Future Trends: More Stress on Entitlements?}

There is some evidence that the command approach to law and its inherent denial of legitimate conflict (and thus of a need for individual counterbalances to the state) is troubling some East German jurists today. A current debate among legal propagandists, for instance, apparently involves a controversy between those who wish legal indoctrination to transmit values and attitudes (meant to ensure conformity of individual behavior with official ideological stan-

" English translation in Soviet Legal Philosophy 111 (H. Babb trans. 1951).

72 See K. Mollnau et al., Macht und Recht-Einheit oder Gegensatz? 78 (1976): "Socialist law is above all a law of commands, of commands requiring creative, socially responsible behavior."

73 The resolution on state-owned enterprises, for example, requires an enterprise to assert-and if need be, enforce-all of its claims. See Verordnung of March 28, 1973, supra note $68, \S 9(3)$. 
dards $)^{74}$ and those who prefer to see more teaching of simple rules and facts (which presumably could be utilized as each citizen saw fit). Although all writing of legal propagandists published until now seem to belong to the first school, the existence of an opposite approach is-disapprovingly-admitted, ${ }^{75}$ and this betrays a growing interest among socialist lawyers in the notion of "entitlements."

The impetus for such a "bourgeois" approach to law seems to come from the area of the economy. In the GDR, the rise of international prices for raw materials, together with the country's own chronic shortage of labor, has produced a situation in which all hopes for economic improvements are centered on "intensification," and in particular on an increase in labor productivity. The East German economy must get more out of its resources, primarily its workers, and for that purpose must improve its incentive systems and match performance with rewards more precisely than in the past. Given the thousands, if not millions, of standardized work norms and targets which determine individual performance, this seems to be very difficult to do. In fact, East German labor lawyers complain that much of the undesirable labor fluctuation in the GDR is due to the fact that rewards are not exactly matched with performance and that workers very quickly find out where they can work less for the same remuneration and accordingly switch jobs. Thus a large part of the current literature in the GDR, including the legal literature, is dedicated to the task of refining the standards of performance in order to increase the accountability of each worker for his product and adjust incentives accordingly.

From an ideological viewpoint, the search for better measurability of performance is justified by the socialist principle of distribution "from each according to his capabilities, to each according to his labor." This "performance principle" was originally introduced by Karl Marx in his Critique of the Gotha Program, which distinguished between a first phase of Communism (later called "Socialism"), in which each would receive from society "according to his labor," and a second higher phase, in which society would be rich enough to give to each "according to his needs." Marx saw the first distribution modus, "according to one's labor," as still seriously flawed by bourgeois notions of justice, because this modus would have to insist on the equivalence of exchange between labor and

"See, e.g., Schirmer, supra note 66, at 132: "Legal indoctrination means above all political-moral education; means the formation of socialist modes of behavior to which all undisciplined, anarchic and subjectivist attitudes are foreign."

is See Edler \& Seidel, Wissenschaftliche Tagung über Probleme des socialistischen Rechtsbewusstseins und der Rechtspropaganda, $30 \mathrm{NJ} 77,78$ (1976). 
wage and therefore, like bourgeois law in general, would have to apply an "equal scale" (quantity and quality of work done) to unequal people. Only in the second stage of Communism, when goods would be distributed "according to need," would this "narrow horizon of bourgeois law" be overcome, and human, rather than formal, equality be established-a kind of justice (or rather non-justice) which would look at each person not as an embodiment of labor but as a human being.

For a long time, the Critique of the Gotha Program seems to have been an embarrassment to socialist jurists. While the "performance principle" itself was always accepted and practiced, its jurisprudential implications have been passed over in silence. In the last few years, however, the attitude toward Marx's analysis seems to have changed. Today, East German jurists openly cite the Critique of the Gotha Program to back up their demands for more accurate measures of economic performance and for more effective work incentives. ${ }^{76}$ Although still not ready to call their search for better measuring and balancing procedures "bourgeois," as Marx had done, they accept the notion (although sometimes with reservations) ${ }^{77}$ that law, as a mechanism for interest coordination, can help to assure the equivalence between labor and remuneration under socialism. The principle "to each according to his labor" has thus significantly influenced the East German way of thinking about law. Lawyers try to define exactly the different components of a work task which will determine a wage ${ }^{78}$ - thus introducing a bourgeois insistence on precision into East German legal thinking. They then carefully balance rewards with performance ${ }^{79}$ - thus using bourgeois "horizontal" techniques rather than the "vertical" policy approach of socialist law. Much more than bourgeois wages, socialist wages are highly individualized (piece rates; individually evaluated plan-fulfillment; a steadily rising number of premiums and

"E.g., Hense \& Thieme, Die Kritik des Gothaer Programms-theoretischkonzeptionelle Grundlage unserer rechtlichen Lohnformgestaltung, 24 STuR 787 (1975).

7 See R. ArLt \& G. STILLER, supra note 62, at 29-30 ("Attempts to explain socialist law as a mere 'regulator,' or to separate the regulating functions of law from law's fundamental social-constructive functions and then to overemphasize the former, are essentially revisionistic.").

7se E. Pätzold, DuRchsetzung des LeistungSPRInziPS (1975).

"Cf. Buchholz, Die Bedeutung des IX. Parteitages der SED und des XXV. Parteitages der KPdSU für die Staats- und Rechtswissenschaft der DDR, 30 NJ 442, 446 (1976)(advocating a more energetic use of sanctions against employees: "[ $[\mathrm{f}$ the performance principle is to be consistently enforced, this requires wages which are carefully differentiated on the basis of actually performed (not just estimated) labor and which account for unsatisfactory or deficient performance through adequate deductions."). 
other monetary rewards) - thus appealing to the private interests of a worker and inviting him to see his rewards as "entitlements."

The perceived need for exact measurability of performance in the GDR economy has thus led to an increased use and theoretical acceptance of criteria which I have earlier linked with the bourgeois understanding of rights. There is some evidence that this understanding is catching on in economy-related areas. East German litigation rates, on a steady trend downward since the early fifties, began to rise again in 1970: by 1975, civil law disputes had increased $125 \%$, and labor law disputes to $168 \%$ of their 1970 level. ${ }^{81}$ The number of disputes handled by social courts, on the other hand, seems to be going down (overall figures are not published ${ }^{82}$ ), which may indicate an increased interest in more formal and rightoriented procedures at the expense of informal, conciliationoriented procedures. Citizens' interest in their civil law rights seems to be rising; when the new Civil Code came out in 1975, two million copies (for a population of seventeen million) were reportedly sold in the first year. Citizens' requests for information from the district courts' information offices seem to be rising as well..$^{83}$

so East German wages in very large part are composed of performance related premiums and bonuses. An average of about 50\% (and occasionally more) of a production worker's present take-home pay comes not from his "basic wage" but from individual rewards for overfulfillment of qualitative or quantitative production targets, participation in socialist competitions, performance of particularly hard or unpleasant work, and from the worker's annual bonus. Some East German authors have objected to this composition of wages: in their opinion the heavy emphasis on incentives gives insufficient consideration to the disparities between people's individual needs and capabilities and reinforces existing social inequalities in the GDR. The principle "to each according to his labor" and its influence on the concept of distributional justice in the GDR is thus criticized from two sides. Conservatives fear that a preoccupation with the equivalence between performance and rewards will induce people to think of law as of a mechanism for interest-coordination and will thus weaken the command-aspects of law. See note 77 supra. Critics on the left fear that the emphasis on precisely measured performance will distract attention from the future goal of communist distribution according to needs. See Rössler \& Seidl, Sozialistische Verteilung und sozialtisches Programm, Wirtschaftswissenschaft 195, 195, 199-201 (1973). These two criticisms betray very. different attitudes towards the individual citizen: the first wants to reduce individual autonomy by increasing the authority of the state, while the second wants to increase individual autonomy by reducing a citizen's dependence on economic and personal constraints. A wage reform presently under way in the GDR, which is designed to reduce the percentage of performance-related rewards to about $20 \%$ of a production worker's total pay, does not seem to imply a diminishing emphasis on individual performance, since official comments stress reinforcement of incentives as one of the purposes of reform.

8I Statistisches Jahrbuch 1976 der Deutschen Demokratischen Republik 433 (1976).

22 Though overall figures are not published, my assumption is based on numerous accounts of the activities of individual social courts or court districts, which fairly consistently report downward trends in their case loads.

${ }^{83}$ Riedel \& Mauck, Zur Tätigkeit der Rechtsauskunftstellen der Kreisgerichte, 27 NJ 509,509 (1973). 
A similar development can be observed in the area of labor law. The 1961 Labor Code, as mentioned earlier, had been intentionally obscure about the exact dimension of workers' participation rights. Building on intervening case law, the new Labor Code of 1977 has now increased union influence on matters directly affecting the individual worker, such as changes in work tasks and determination of bonuses. While union participation in enterprise policy decisions is still left intentionally vague and amounts at best to task-sharing (that is, involvement in the execution of projects designed by others) rather than power-sharing (that is, a precisely-defined sharing of influence on the making of a particular decision), the unions' function as the individual worker's interest representative seems to be gaining in importance. Union publications have become more vocal in their criticism of managers' disregard for union rights. ${ }^{84}$ The Federation of East German Unions, in a series of Directives for the Use of Socialist Law, has increasingly stressed the need for securing the legal rights of individual workers. ${ }^{85}$ The participation of union representatives in individual labor disputes seems to be growing. ${ }^{86}$ In an apparently rising number of instances, union organizations arrange legal advice for their members, organize "law conferences," and are more and more inclined to view law as a weapon to defend the individual worker's rights. ${ }^{87}$ Eventually, it may prove difficult to prevent the growing demand for interest representation from spreading into policy areas as well; admonitions that "discussions about decisions from 'above' and democracy from 'below' lead to nothing"s8 at least seem to betray some tensions.

In certain areas of East German social life, in particular those related more directly to the economy, individual rights are increasingly understood and apparently asserted in a "bourgeois" way as entitlements, weapons, and guarantees of individual autonomy. To some extent, this understanding is even encouraged by the state. East German legal propaganda stresses the enforcement of employee rights as a means of strengthening the incentive system within the socialist economy, and it propogates the enforcement of

s $C$. Interview with V. Schmidt, Judge of the Kammer für Arbeitsrecht, Stadtbezirksgericht Belin-Köpenich, in Tribüne, Aug. 7, 1975, supplement Die Konfliktkommission, no. 3], at 3, col. 2 ("It's not a wish to quarrel. The legal consciousness of workers has grown from year to year. They have simply become less acquiescent and so, incidentally, have the unions. They have less patience with bad management, and that's the way it should be.").

* See Bundesvorstand des FDGB (Rechtsabteilung), Gewerkschaftuiche Ordnungen zUR DuRChSETZUNG DES SOZIALISTISCHEN RECHTS (Schriftenreihe über Arbeitsrecht no. 151968 ).

* See Heintze, Arbeiterklasse, Gewerkschaften und sozialistisches Recht, 27 NJ 219, 221 (1973).

n See Rechtskomissionen bewähren sich, DIE ARBEIT no. 11 at 28 (1974).

* Berger, Sozialistische Demokratie im Betrieb, 25 EinheIT 723, 728 (1970). 
buyers' rights as a means of checking the chronic inefficiency of the state-owned consumer industry.

However, the new and partial emphasis on rights as entitlements rather than policy pronouncements introduces a potentially disruptive element into socialist legal thinking. Citizens who feel encouraged to insist on "their rights" in one area of life might very well be tempted to insist on their rights in other areas as well. The present civil rights movement in the socialist countries is an obvious example: socialist dissenters today refuse to interpret their countries' constitutions as the policy directives they were meant to be and instead lay claim to the protective and autonomy-enhancing function of constitutional rights. A debate about civic participation or "socialist democracy" in East Germany today seems to involve the same issues of autonomy and rights, ${ }^{89}$ though in much less radical fashion, and remarks that "no search for new [participation] forms is necessary" imply that some people have indeed suggested such new forms. Socialist legal propaganda appears aware of the danger of a growing bourgeois "right-consciousness" and tries to contain and counterbalance the limited recognition of entitlements with increased emphasis on the guiding function of socialist law. Citizens are reminded that they cannot expect to receive the blessings of the law without giving first: "every beneficial effect which the socialist law may have for the individual citizen is directly dependent upon his democratic activism and his civic responsibility." "91 Bourgeois emphasis on precision and procedure is criticized as formal and forbidding: "It is an essential strength of socialist law that it rejects the impersonal coldness of supposed objectivity which characterizes capitalist legal systems." 92 It remains to be seen whether spillover effects can indeed be prevented.

* See the contributions to the conference on state, law and democracy on June 24 and 25, 1974 in Berlin, in StaAt, Recht und Demokratie, supra note 56.

0 Petzold, Referentenkonferenz über Aufgaben der Staats- und Rechtspropaganda nach dem IX. Parteitag der SED, 30 NJ 591, 592 (1976).

"Dettenborn \& Mollnau, Uberlegungen zum Inhalt der sozialistischen Rechtserziehung, 30 NJ 281, 283 (1976).

82 Öberlander, in: StaAT, Recht und Demokratie, supra note 56, at 286, 288. 